\title{
Effect of iron, zinc and manganese shortage-induced change on photosynthetic pigments, some osmoregulators and chlorophyll fluorescence parameters in lettuce
}

\author{
H.R. ROOSTA*, A. ESTAJI",+, and F. NIKNAM ${ }^{* *}$ \\ Department of Horticultural Sciences, Faculty of Agriculture, Vali-E-Asr University of Rafsanjan, Iran* \\ Department of Agronomy, Faculty of Agriculture, Vali-E-Asr University of Rafsanjan, Iran ${ }^{* *}$
}

\begin{abstract}
Although the beneficial role of $\mathrm{Fe}, \mathrm{Zn}$, and $\mathrm{Mn}$ on many physiological and biochemical processes is well established, effects of each of these elements on chlorophyll (Chl) $a$ fluorescence and photosynthetic pigment contents is not well studied. The objective of this study was to evaluate effects of Fe, $\mathrm{Zn}$, and Mn deficiency in two lettuce cultivars. The parameters investigated could serve also as physiological and biochemical markers in order to identify stress-tolerant cultivars. Our results indicated that microelement shortage significantly decreased contents of photosynthetic pigments in both lettuce cultivars. Chl $a$ fluorescence parameters including maximal quantum yield of PSII photochemistry and performance index decreased under micronutrient deficiency, while relative variable fluorescence at J-step and minimal fluorescence yield of the dark-adapted state increased under such conditions in both cultivars. Micronutrient deficiency also reduced all parameters of quantum yield and specific energy fluxes excluding quantum yield of energy dissipation, quantum yield of reduction of end electron acceptors at the PSI, and total performance index for the photochemical activity. Osmoregulators, such as proline, soluble sugar, and total phenols were enhanced in plants grown under micronutrient deficiency. Fe, Zn, and Mn deficiency led to a lesser production of dry mass. The Fe deficiency was more destructive than that of $\mathrm{Zn}$ and Mn on the efficiency of PSII in both lettuce cultivars. Our results suggest that the leaf lettuce, which showed a higher efficiency of PSII, electron transport, quantum yield, specific energy fluxes, and osmoregulators under micronutrient deficiency, was more tolerant to stress conditions than crisphead lettuce.
\end{abstract}

Additional key words: chlorophyll fluorescence transients, micronutrient, Lactuca sativa, quantum yield.

\section{Introduction}

Lettuce is one of the important plants for human health because of various vitamins and essential ingredients. Lettuce also is important to facilitate intestinal peristalsis because of high amount of cellulose and fiber (Xue et al. 2001). Due to its high contents of folate and minerals, lettuce is beneficial for human body. Potassium is another important mineral of lettuce, which helps controlling heart rate and blood pressure, while manganese has also a wide range of functions in our body, especially as a component of metalloenzymes (Xue et al. 2001).

Due to different environmental stresses, planting lettuce in hydroponic systems has expanded widely all over the world. One of the major problems in hydroponic systems is the nutrient management (Petrazzini et al. 2014). Although iron, manganese, zinc, and other microelements are essential for plant physiological reactions, their role in electron transport chain is less understood. Fe is a part of cytochrome, which plays an important role

Received 16 July 2016, accepted 1 December 2016, published as online-first 8 February 2017.

${ }^{+}$Corresponding author; phone: +989192681257, e-mail: estaji1366@gmail.com

Abbreviations: Area - area above the OJIP curve, it expresses the size of the reduced PQ pool; Chl - chlorophyll; DM - dry mass; $\mathrm{ET}_{0} / \mathrm{RC}$ - electron transport flux per RC; FeD - iron deficiency; FM - fresh mass; $\mathrm{F}_{\mathrm{m}}$ - maximal fluorescence of the dark-adapted state; $\mathrm{F}_{\mathrm{o}}$ - minimal fluorescence yield of the dark-adapted state; $\mathrm{F}_{\mathrm{v}}$ - maximal variable fluorescence; $\mathrm{F}_{\mathrm{v}} / \mathrm{F}_{\mathrm{m}}$ - maximal quantum yield of PSII photochemistry; MnD - manganese deficiency; PI - performance index; PIabs - performance index for the photochemical activity; PItot - total performance index for the photochemical activity; $\mathrm{RC}$ - reaction center; $\mathrm{SM}$ - normalized area related to the number of electron carriers per electron transport chain; TChl - total chlorophyll; TRo/RC - trapped energy flux per $\mathrm{RC} ; \mathrm{V}_{\mathrm{i}}-$ relative variable fluorescence at time $30 \mathrm{~ms}$ I-step after start of actinic light pulse; $\mathrm{V}_{\mathrm{j}}$ - relative variable fluorescence at J-step; ZIP - zinc transporters proteins; $\Phi_{\mathrm{do}}-$ quantum yield of energy dissipation; $\varphi \mathrm{ET}_{20}$ - quantum yield of electron transport from $\mathrm{Q}_{\mathrm{A}}$ to $\mathrm{Q}_{\mathrm{B}}$ in PSII; $\Phi_{\mathrm{po}}-$ maximum quantum yield of primary PSII photochemistry; $\Phi_{\mathrm{re} 10}$ - quantum yield of reduction of end electron acceptors at the PSI; $\Psi_{\mathrm{o}}$ - trapped exiton moves an electron in to the electron transport chain beyond $\mathrm{Q}_{\mathrm{A}} ; \mathrm{ZnD}$ - zinc deficiency. 
in electron transport chain. Likewise, ferredoxin contains $\mathrm{Fe}$ and participates in electron transport, oxidation, and reduction reactions (Barker and Pilbeam 2015). Zinc is another essential element in plants and animals, is a part of enzymatic redox reactions, and is essential for energy transport, protein synthesis, protection of protein structure and cellular membrane structures (Aravind and Prasad 2004). Manganese also is one of the microelements that enables water splitting in PSII.

In hydroponic systems, micronutrient-deficiency symptoms appear due to changes in $\mathrm{pH}$ and temperature, therefore recognizing these signs could help to a better feeding management (Bityutskii et al. 2014). Microelements shortage disarranges photosynthetic systems and reduces amount of Chl. Meanwhile, lack of Fe, $\mathrm{Zn}$, and Mn leads to decomposition of D1 protein in the reaction center of PSII (Bertamini et al. 2001). Fe deficiency (FeD) causes reduction in chloroplast proteins, concentration of $\mathrm{Chl}$, and photochemical efficiency (Morales et al. 1991). This reduction in $\mathrm{Chl}$ and protein content changes ultrastructure of the thylakoid membrane (Terry and Abadía 1986). Timperio et al. (2007) reported that FeD significantly reduced amount of PSI proteins, while PSII proteins were less affected by this stress. $\mathrm{Zn}$ deficiency $(\mathrm{ZnD})$ reduced plant growth by decreasing photosynthetic rate (Henriques 2001), disorganization of chloroplast thylakoids, degeneration of chloroplast membrane, and reducing photochemical efficiency of PSII (Donnini et al. 2013). Nutrient deficiency increases electron excitation energy and reduces number of carried electrons by electron transport chain (Evans and Terashima 1987). On the other hand, Mn deficiency $(\mathrm{MnD})$ causes significant reduction in transported electrons between two photosystems. $\mathrm{MnD}$ can reduce $\mathrm{Mg}^{2+}$-ATPase and $\mathrm{Ca}^{2+}$-ATPase activities, and rate of photophosphorylation in thylakoid membranes of maize chloroplast (Qu et al. 2012).

Recently, Chl fluorescence analysis has become one of the most quick, reliable, powerful and simple methods to collect information about PSII and electron transport (Kalaji et al. 2014, Osório et al. 2014). The OJIP-test is common for evaluating the response of plant species under stress conditions (Strasser et al. 2000, Percival and Henderson 2003). Chl fluorescence, produced by excited

\section{Materials and methods}

Plant material and growth conditions: This experiment was conducted during the 2015 growing season at the experimental greenhouse of Vali-e-Asr University. The experiment was arranged as a factorial in the framework of completely randomized design with three replications. Two lettuce cultivars, including crisphead (Lactuca sativa var. capitata) and leaf lettuce (Lactuca sativa var. crispum), were treated by micronutrient deficiency, including control, FeD, $\mathrm{ZnD}$, and $\mathrm{MnD}$. Seeds were planted in trays containing perlite. After fifteen days, at four-leaf stage, seedlings were transferred to a 5-L buckets
Chl molecules, is a nondestructive biomarker for evaluating effects of stress on PSII (Strasser et al. 2000, Kalaji and Loboda 2007, Tuba et al. 2010, Oukarroum et al. 2015). PSII sensitivity is considered as a basic parameter to estimate plant response under micronutrient changes. Donnini et al. (2013) reported that FeD decreased maximal variable fluorescence $\left(\mathrm{F}_{\mathrm{v}}\right)$ and maximal quantum yield of PSII photochemistry $\left(\mathrm{F}_{\mathrm{v}} / \mathrm{F}_{\mathrm{m}}\right)$ ratio in cucumber. Increasing $\mathrm{Chl}$ fluorescence under micronutrient deficiency was previously reported in sunflower (Ciompi et al. 1996), wheat (Shangguan et al. 2000), maize, and tomato (Chaves et al. 2003).

Osmoregulation, is an important plant mechanism how to reduce negative effects of stresses. Osmoregulation leads to accumulating low-molecular-mass and nontoxic organic compounds, such as osmoregulators (Chaves et al. 2003). Biosynthesis and accumulation of osmoregulators in vacuole and cytosol, e.g., soluble sugars, proline, phenolic compounds, and others compounds, may be involved in membrane stability, especially, of thylakoid membrane (Fu et al. 2015). Therefore osmotic adjustments could increase electron transport as a result of increasing membrane stability. Cultivars with the ability to produce better osmotic adjustments have more efficient photosynthesis under stress conditions. Sperotto et al. (2007) reported an increasing rate of soluble sugar accumulation in plants grown under $\mathrm{FeD}$. In rice plants, $\mathrm{ZnD}$ induced accumulation of carbohydrates and starch molecules in roots and shoots (Suzuki et al. 2012).

Since, crisphead (Lactuca sativa var. capitata) and leaf lettuce (Lactuca sativa var. crispum) are the two most common lettuce cultivars planted in Iran greenhouses and micronutrient deficiency reduces the formation and growth of lettuce head, the objectives of our work were: $a$ ) to evaluate effects of $\mathrm{Fe}, \mathrm{Zn}$, and $\mathrm{Mn}$ on lettuce photosynthesis by analyzing $\mathrm{Chl}$ fluorescence parameters; $b$ ) to investigate effects of Fe, $\mathrm{Zn}$, and Mn deficiency on photosynthetic pigment contents, proline, phenolic compounds, and soluble sugar concentration in lettuce plants; $c$ ) to compare micronutrient-stress tolerance of two commercial lettuce cultivar utilizing $\mathrm{Chl}$ fluorescence parameters as physiological and biochemical markers.

(upper diameter of $30 \mathrm{~cm}$, lower diameter of $20 \mathrm{~cm}$, and $25 \mathrm{~cm}$ high) containing a nutrient solution. Seedlings were grown under greenhouse conditions with relative humidity of $50 \pm 10 \%$, temperature of $25 / 15 \pm 2^{\circ} \mathrm{C}$ (day/night), and a 13/11 h photoperiod. During this period, seedlings were nourished with nutrient solutions containing $5 \mathrm{mM}$ $\mathrm{Ca}\left(\mathrm{NO}_{3}\right)_{2} .4 \mathrm{H}_{2} \mathrm{O}, 0.2 \mathrm{mM} \mathrm{KH}_{2} \mathrm{PO}_{4}, 0.2 \mathrm{mM} \mathrm{K} \mathrm{K}_{2} \mathrm{SO}_{4}$, $0.3 \mathrm{mM} \mathrm{MgSO}_{4} .7 \mathrm{H}_{2} \mathrm{O}$, and $0.1 \mathrm{mM} \mathrm{NaCl}$. Microelements were $7 \mu \mathrm{M} \quad \mathrm{MnSO}_{4} . \mathrm{H}_{2} \mathrm{O}, 0.7 \mu \mathrm{M} \quad \mathrm{ZnSO}_{4}, 0.8 \mu \mathrm{M}$ $\mathrm{CuSO}_{4} .5 \mathrm{H}_{2} \mathrm{O}, 2 \mu \mathrm{M} \mathrm{H}_{3} \mathrm{BO}_{3}, 0.8 \mu \mathrm{M} \mathrm{Na}_{2} \mathrm{MoO}_{4} .2 \mathrm{H}_{2} \mathrm{O}$, and $20 \mu \mathrm{M}$ of Fe-ethylenediamine di-2-hydroxyphenyl acetate 
(EDDHA) under control conditions (Roosta and Schjoerring 2007). The nutrient solution $(\mathrm{pH} 6.5 \pm 0.1)$ was renewed every $3 \mathrm{~d}$. Twenty days after transferring seedlings into pots, the composition of nutrient solution changed in each experimental plot, according to the treatment plan. In this step, $\mathrm{Fe}, \mathrm{Zn}$, and $\mathrm{Mn}$ were omitted from nutrient solution in each treatment for threee weeks. The solution in every pot was changed weekly and $\mathrm{pH}$ was checked daily. In this experiment, all parameters were measured after nutrient deficiency for three weeks.

Dry mass: At the end of experiment, the plants were harvested from each pot and divided to shoots and roots. Fresh mass (FM) was measured immediately after harvest and dry mass (DM) was obtained when samples were dried in oven for $72 \mathrm{~h}$ at $70^{\circ} \mathrm{C}$.

Total Chl and carotenoids (Car): Chl pigments (Chl $a$, $\mathrm{Chl} b$, and TChl) and Car contents were measured at the end of the experiment according to Lichtenthaler (1987). Middle part of the youngest fully expanded leaf was collected and wrapped in aluminum foil to avoid degradation of pigments by light. One gram of fresh leaves was ground with $10 \mathrm{ml}$ of $80 \%$ aqueous acetone in mortar and pestle. After filtering, absorbance of the centrifuged extracts was measured at 480,510,645, 652, and $663 \mathrm{~nm}$ using a spectrophotometer (U-2000, Hitachi Instruments, Tokyo, Japan).

Proline content: To determine the free-proline concentration, the youngest fully expanded leaf of sample plants $(0.5 \mathrm{~g})$ were homogenized with $5 \mathrm{ml}$ of $95 \%$ ethanol. The insoluble fraction of the extract was washed with $5 \mathrm{ml}$ of $70 \%$ ethanol. Extracts were centrifuged at 3,500 rpm for $10 \mathrm{~min}$ and the supernatant was preserved at $4^{\circ} \mathrm{C}$ for the proline determination. An aliquot of this supernatant was taken, reactive ninhydrin acid reagent (ninhydrin, $6 \mathrm{M}$ phosphoric acid and glacial acetic acid at 99\%) was added, and then placed in a bath at $100^{\circ} \mathrm{C}$. After $45 \mathrm{~min}$, samples were cooled and absorbance was determined at $520 \mathrm{~nm}$ using a spectrophotometer (U-2000, Hitachi Instruments, Tokyo, Japan). The proline concentration was calculated according to a standard curve and expressed as $\mu \mathrm{g} \mathrm{g}^{-1}(\mathrm{FM})$.

Soluble sugar content: The soluble sugars were extracted by adding $10 \mathrm{ml}$ ethanol (alcoholic extracts, the same as for proline) and mixed with antron (200 $\mathrm{mg}$ of antron + $100 \mathrm{ml}$ of $72 \%$ sulphuric acid). Tubes were heated in boiling water bath for $10 \mathrm{~min}$. Then samples were cooled and absorbance was measured at $625 \mathrm{~nm}$ by the above spectrophotometer. The concentration of soluble sugars was calculated using the standard curve and the results were expressed as $\mathrm{mg} \mathrm{g}^{-1}(\mathrm{FM})$.
Elemental analysis: Leaf and root contents of $\mathrm{Fe}, \mathrm{Zn}$, and Mn were quantified as described previously by Roosta and Mohsenian (2012). Leaf and root samples were ground and dry-ashed at $550^{\circ} \mathrm{C}$ for $4 \mathrm{~h}$. The ashes were dissolved with $5 \mathrm{ml}$ of $2 \mathrm{~N} \mathrm{HCl}$ and made up to $50 \mathrm{ml}$ with distillated water. The concentrations of $\mathrm{Fe}, \mathrm{Zn}$, and $\mathrm{Mn}$ were measured by atomic absorption spectrometry (Version 1/33 GBC Avanta, Australia). The results were expressed as $\mathrm{mg} \mathrm{kg}^{-1}(\mathrm{DM})$.

Phenolic compounds: The extraction was carried out according to Isfendiyaroglu and Ozeker (2002). Fresh plant material was mixed with $95 \%$ ethanol $(5 \mathrm{ml})$ and kept in dark condition for $48 \mathrm{~h}$. Then $1 \mathrm{ml}$ of ethanol was added to $1 \mathrm{ml}$ of the supernatant and distilled water added to make a total volume of $5 \mathrm{ml}$. Folin reagent $(0.5 \mathrm{ml}$ of $50 \%)$ and $1 \mathrm{ml}$ of $5 \%$ calcium carbonate were added to samples which changed their color to black. In this step, samples were placed in dark place for $1 \mathrm{~h}$ and the phenolic compound content was measured at $725 \mathrm{~nm}$ by the above spectrophotometer. Phenolic compound concentration was calculated according to a standard curve and expressed as $\mu \mathrm{g} \mathrm{g} \mathrm{g}^{-1}(\mathrm{FM})$.

Chl fluorescence parameters were measured and calculated at the end of nutrient-deficiency period, $41 \mathrm{~d}$ after planting, by portable photosynthetic efficiency analyzer (PEA, Hansatech Inc. Co., UK). The parameters included variable fluorescence $\left(\mathrm{F}_{\mathrm{v}}\right)$, maximal fluorescence of the dark-adapted state $\left(\mathrm{F}_{\mathrm{m}}\right)$, minimal fluorescence yield of the dark-adapted state $\left(\mathrm{F}_{\mathrm{o}}\right), \mathrm{F}_{\mathrm{v}} / \mathrm{F}_{\mathrm{m}}$, Area (area above the OJIP curve, which expresses the size of the reduced PQ pool), relative variable fluorescence at time $30 \mathrm{~ms}$ at the I-step after start of actinic light pulse $\left(\mathrm{V}_{\mathrm{i}}\right)$, relative variable fluorescence at the J-step $\left(V_{j}\right), F_{v} / F_{0}$, the relative number of electron carriers per electron transport chain $\left(\mathrm{S}_{\mathrm{m}}\right)$, and performance index (PI). Fully expanded leaves were collected from each pot and adapted to a dark period for $15 \mathrm{~min}$ by fixing special tags on each upper leaf blade before taking measurements. After 15 min of dark adaptation, the sensor cup was fitted on the leaf for measurement. The Chl fluorescence transients were induced by a red light up to $3,500 \mu \mathrm{mol}$ (photon) $\mathrm{m}^{-2} \mathrm{~s}^{-1}$ and recorded from $10 \mu \mathrm{s}$ up to $1 \mathrm{~s}$ with a peak wavelength of $627 \mathrm{~nm}$. The fluorescence transients were analyzed according to the equations of the JIP-test (Strasser et al. 2000).

Statistical analysis: All data were analyzed via $S A S$ software, SAS Institute, Cary, NC, USA. When analysis of variance $(A N O V A)$ showed significant treatment effects, the least significant differences (LSD) test was applied to compare means at $P<0.05$. The biophysical parameters were calculated with the help of the "PEA Plus" software package, version 1.02 . 


\section{Results}

Ion concentrations: As we expected, micronutrient deficiency, caused by Fe, Zn, and Mn had significant effect on $\mathrm{Fe}, \mathrm{Zn}$, and $\mathrm{Mn}$ contents (Table $1 \mathrm{~S}$, supplement available online). The Fe concentration was severely reduced in the plants grown under $\mathrm{FeD}$ and $\mathrm{MnD}$ conditions and the highest Fe concentration was observed in the plants grown under $\mathrm{ZnD}$ (Table 1). FeD and $\mathrm{MnD}$ treatments significantly increased $\mathrm{Zn}$ concentration, while $\mathrm{ZnD}$ treatment decreased $\mathrm{Zn}$ concentration significantly. The highest $\mathrm{Zn}$ concentration were observed in crisphead under FeD condition and the lowest $\mathrm{Zn}$ concentrations were observed in leaf lettuce under $\mathrm{ZnD}$ condition. Under $\mathrm{MnD}, \mathrm{Mn}$ concentration in leaves of leaf lettuce and crisphead cultivar decreased by $26.7 \%$ and $18.4 \%$, respectively. By contrast, after $\mathrm{FeD}$ and $\mathrm{ZnD}$ treatments, the Mn concentration in leaves was stable in both cultivars (Table 1).

Osmotic regulating compounds: Proline and total phenolic components were significantly affected by micronutrient deficiency, cultivar, and their interaction. The soluble sugar content was not significantly affected by interaction of micronutreint deficiency and cultivar (Table 1S). Proline and total phenol components in lettuce leaves increased by micronutrient deficiency. The highest proline and total phenol contents in leaves were observed in leaf lettuce under FeD and the lowest proline and lowest total phenol contents were observed in crisphead lettuce under control conditions (Table 1). In both cultivars, soluble sugar contents were enhanced by increasing micronutrient deficiency.

Pigment content: In both cultivars, reduction of Fe, $\mathrm{Zn}$ and $\mathrm{Mn}$ caused a decrease in photosynthetic pigment concentrations. Chl $a$ and TChl significantly decreased, compared with control, under micronutrient deficiency in both cultivars. Maximum reduction of Chl $a$ and TChl occurred in crisphead lettuce, by 35 and $28 \%$ under FeD, respectively. $\mathrm{Zn}$ and $\mathrm{Mn}$ shortage showed a lesser impact on the amount of Chl $a$ and TChl than that of FeD (Fig. 1). Regardless of lettuce cultivars, omitting micronutrients from the nutrient solution significantly decreased the

Table 1. Effect of micronutrient deficiency on ion concentration $\left(\mathrm{Fe}^{2+}, \mathrm{Zn}^{2+}, \mathrm{Mn}^{2+}\right)$ in leaves of lettuce cultivars. Values are means \pm $\mathrm{SE}$ of three replicates. Different letters in each column show significant differences at $P \leq 0.05$ (LSD). DM - dry mass; FM - fresh mass.

\begin{tabular}{|c|c|c|c|c|c|c|c|}
\hline $\begin{array}{l}\text { Micronutrient } \\
\text { deficiency }\end{array}$ & Cultivar & $\begin{array}{l}\mathrm{Fe} \\
{\left[\mathrm{mg} \mathrm{kg}^{-1}(\mathrm{DM})\right]}\end{array}$ & $\begin{array}{l}\mathrm{Zn} \\
{\left[\mathrm{mg} \mathrm{kg}^{-1}(\mathrm{DM})\right]}\end{array}$ & $\begin{array}{l}\mathrm{Mn} \\
{\left[\mathrm{mg} \mathrm{kg}^{-1}(\mathrm{DM})\right]}\end{array}$ & $\begin{array}{l}\text { Proline } \\
{\left[\mu \mathrm{g} \mathrm{g}^{-1}(\mathrm{FM})\right]}\end{array}$ & $\begin{array}{l}\text { Soluble sugar } \\
{\left[\mu \mathrm{g} \mathrm{g}^{-1}(\mathrm{FM})\right]}\end{array}$ & $\begin{array}{l}\text { Total phenol } \\
{\left[\mu \mathrm{g} \mathrm{g}^{-1}(\mathrm{FM})\right]}\end{array}$ \\
\hline Control & $\begin{array}{l}\text { Leaf lettuce } \\
\text { Crisphead }\end{array}$ & $\begin{array}{l}71.6 \pm 1.8^{\mathrm{b}} \\
66.3 \pm 0.8^{\mathrm{c}}\end{array}$ & $\begin{array}{l}28.3 \pm 0.8^{\mathrm{d}} \\
32.2 \pm 0.8^{\mathrm{c}}\end{array}$ & $\begin{array}{l}51.6 \pm 1.3^{\mathrm{a}} \\
52.3 \pm 1.3^{\mathrm{a}}\end{array}$ & $\begin{array}{l}82 \pm 1.5^{\mathrm{d}} \\
81.6 \pm 2.8^{\mathrm{d}}\end{array}$ & $\begin{array}{l}2.50 \pm 0.05^{\mathrm{a}} \\
2.00 \pm 0.05^{\mathrm{a}}\end{array}$ & $\begin{array}{l}83.0 \pm 1^{\mathrm{f}} \\
72.6 \pm 1.2^{\mathrm{g}}\end{array}$ \\
\hline $\mathrm{Fe}(-)$ & $\begin{array}{l}\text { Leaf lettuce } \\
\text { Crisphead }\end{array}$ & $\begin{array}{l}56.7 \pm 1.5^{\mathrm{e}} \\
47.0 \pm 2.6^{\mathrm{f}}\end{array}$ & $\begin{array}{l}38.0 \pm 1.6^{\mathrm{b}} \\
41.0 \pm 0.6^{\mathrm{a}}\end{array}$ & $\begin{array}{l}52 \pm 1.6^{\mathrm{a}} \\
58 \pm 1.6^{\mathrm{a}}\end{array}$ & $\begin{array}{l}99 \pm 3.6^{\mathrm{a}} \\
94 \pm 4.6^{\mathrm{b}}\end{array}$ & $\begin{array}{l}3.53 \pm 0.10^{\mathrm{a}} \\
3.40 \pm 0.05^{\mathrm{a}}\end{array}$ & $\begin{array}{l}121.7 \pm 0.8^{\mathrm{a}} \\
115.7 \pm 0.9^{\mathrm{bc}}\end{array}$ \\
\hline Zn (-) & $\begin{array}{l}\text { Leaf lettuce } \\
\text { Crisphead }\end{array}$ & $\begin{array}{l}80.0 \pm 4.8^{\mathrm{a}} \\
72.0 \pm 1.6^{\mathrm{b}}\end{array}$ & $\begin{array}{l}21.6 \pm 0.8^{\mathrm{f}} \\
25.0 \pm 2.6^{\mathrm{e}}\end{array}$ & $\begin{array}{l}50.6 \pm 1.8^{\mathrm{a}} \\
52.6 \pm 1.3^{\mathrm{a}}\end{array}$ & $\begin{array}{l}93 \pm 2.5^{\mathrm{c}} \\
96 \pm 5.5^{\mathrm{b}}\end{array}$ & $\begin{array}{l}3.50 \pm 0.03^{\mathrm{a}} \\
3.13 \pm 0.03^{\mathrm{a}}\end{array}$ & $\begin{array}{l}116.6 \pm 0.9^{b} \\
113 \pm 0.5^{c}\end{array}$ \\
\hline $\operatorname{Mn}(-)$ & $\begin{array}{l}\text { Leaf lettuce } \\
\text { Crisphead }\end{array}$ & $\begin{array}{l}68.3 \pm 2.3^{\mathrm{c}} \\
62.3 \pm 3.1^{\mathrm{d}}\end{array}$ & $\begin{array}{l}33.0 \pm 0.6^{\mathrm{c}} \\
32.0 \pm 3.3^{\mathrm{c}}\end{array}$ & $\begin{array}{l}36.3 \pm 3.3^{c} \\
42.7 \pm 2.5^{b}\end{array}$ & $\begin{array}{l}91 \pm 3.6^{\mathrm{c}} \\
92 \pm 2.1^{\mathrm{c}}\end{array}$ & $\begin{array}{l}2.86 \pm 0.03^{\mathrm{a}} \\
2.60 \pm 0.10^{\mathrm{a}}\end{array}$ & $\begin{array}{l}103 \pm 0.8^{\mathrm{d}} \\
97.3 \pm 0.1^{\mathrm{e}}\end{array}$ \\
\hline
\end{tabular}

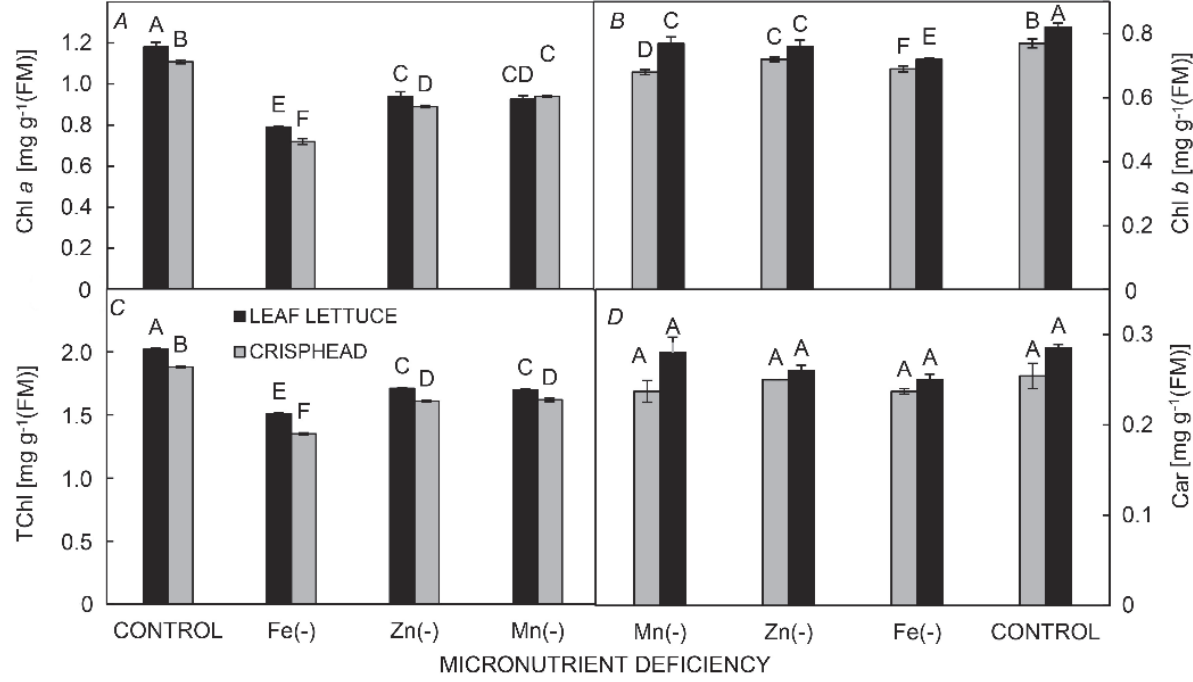

Fig. 1. Effect micronutrition deficiency on chlorophyll $(\mathrm{Chl}) a(A)$, $\mathrm{Chl} b(B)$, TChl $(C)$, and carotenoids (Car) $(D)$ of two lettuce cultivars: leaf and crisphead lettuce. Bars indicate standard error. Columns with different letters are significantly different at $P \geq 0.05$. 


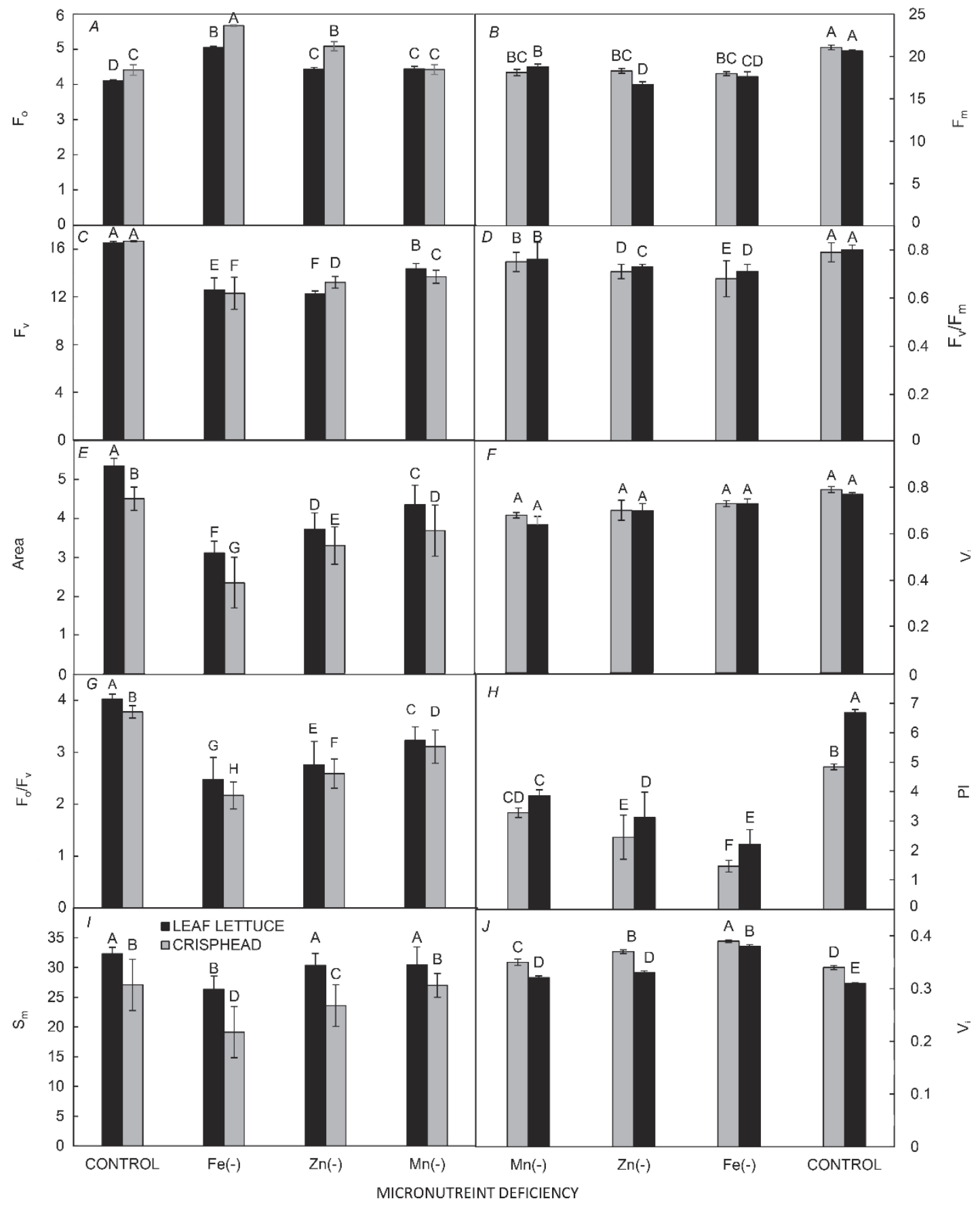

Fig. 2. Effect of micronutrient deficiency on chlorophyll fluorescence parameters of two lettuce cultivars: leaf lettuce and crisphead lettuce. Bars indicate standard error. Columns with different letters are significantly different at $P \geq 0.05$.

amount of Chl $b$ in comparison with control. The maximum reduction of $\mathrm{Chl} b$ was recorded in the plants grown under FeD, while there was no significant change in the plants grown under $\mathrm{MnD}$ and $\mathrm{ZnD}$. In general, Chl $b$ reduction in crisphead lettuce was higher than that in leaf lettuce (Fig. 1). Data also indicated that micronutrient deficiency had no significant effect on the Car content (Table 2S, supplement available online). But the Car contents after $\mathrm{FeD}, \mathrm{ZnD}$, and $\mathrm{MnD}$ treatments slightly decreased in comparition with control treatment (Fig. 1D).

Chl fluorescence parameters including $F_{v}, F_{m}, F_{o}, F_{v} / F_{m}$, Area, $V_{\mathrm{i}}, \mathrm{V}_{\mathrm{j}}, \mathrm{F}_{\mathrm{v}} / \mathrm{F}_{\mathrm{o}}, \mathrm{S}_{\mathrm{m}}$, and PI were significantly affected by microelement deficiency (Table $3 \mathrm{~S}$, supplement available online). As indicated in Fig. $2, \mathrm{~F}_{\mathrm{v}}, \mathrm{F}_{\mathrm{m}}, \mathrm{F}_{\mathrm{o}}, \mathrm{F}_{\mathrm{v}} / \mathrm{F}_{\mathrm{m}}$, Area, $F_{\mathrm{v}} / \mathrm{F}_{\mathrm{o}}, \mathrm{S}_{\mathrm{m}}$, and PI decreased by microelement deficiency, especially by FeD. FeD in crisphead cultivar caused 13,56 , and $69 \%$ reduction in $\mathrm{F}_{\mathrm{v}} / \mathrm{F}_{\mathrm{m}}$, Area, and PI, 


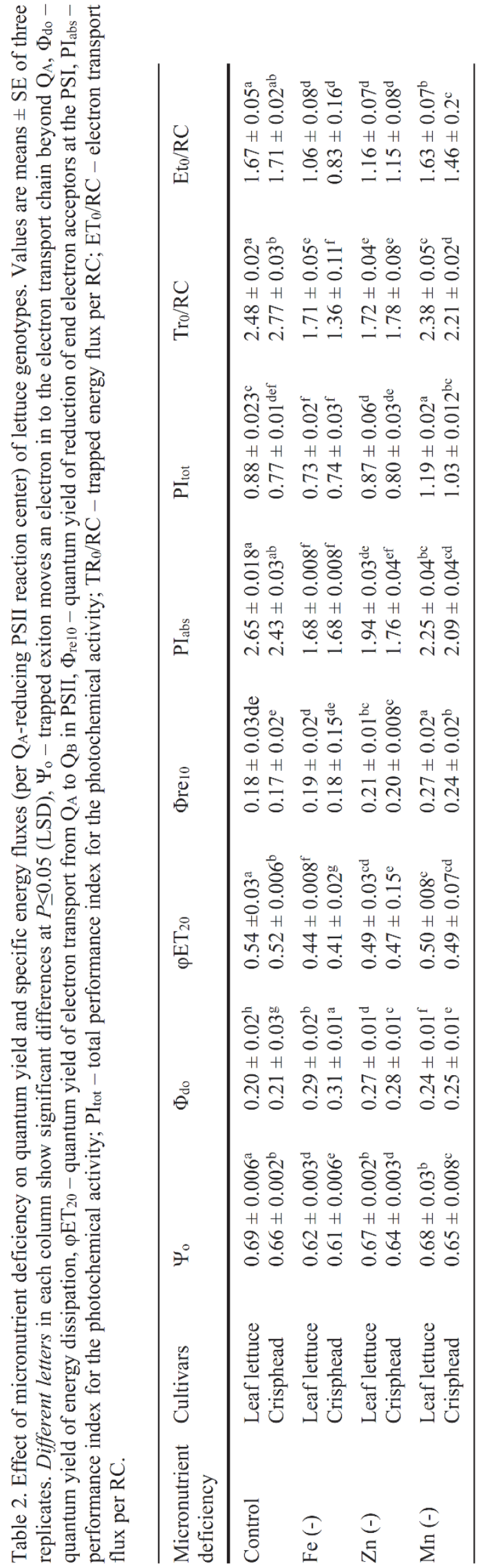

respectively. Leaf lettuce cultivar showed lesser sensitivity compairing to the crisphead cultivar (Fig. 2D,E,H). In addition, data showed that $\mathrm{ZnD}$ affected more $\mathrm{Chl}$ fluorescence parameters in comparison with $\mathrm{MnD}$. According to our data, $\mathrm{V}_{\mathrm{j}}$ and $\mathrm{F}_{\mathrm{o}}$ parameters increased by microelement deficiency treatments. Regardless of lettuce cultivars, $\mathrm{FeD}, \mathrm{ZnD}$, and $\mathrm{MnD}$, comparing with control, increased $\mathrm{F}_{\mathrm{o}}$ value by 26,12 , and $4 \%$, respectively (Fig. 2A). The $\mathrm{V}_{\mathrm{j}}$ value increased under micronutrient deficiency. The maximum increase was recorded in leaf lettuce grown under $\mathrm{FeD}$ and the minimum increase was observed in crisphead lettuce grown under MnD (Fig. 2J). Leaf lettuce cultivar showed higher tolerance towards micronutrient deficiency according to $\mathrm{Chl}$ fluorescence parameters, comparing to crisphead lettuce.

Quantum yields and specific energy fluxes: Lack of micronutrients had a significant effects on quantum yield parameters of PSII including trapped exiton (which moves an electron in to the electron transport chain beyond $\mathrm{Q}_{\mathrm{A}}$, $\left.\Psi_{\mathrm{o}}\right)$, quantum yield of energy dissipation $\left(\Phi_{\mathrm{do}}\right)$, quantum yield of electron transport from $\mathrm{Q}_{\mathrm{A}}$ to $\mathrm{Q}_{\mathrm{B}}$ in PSII ( $\left.\varphi_{\mathrm{ET} 20}\right)$, quantum yield of reduction of end electron acceptors at the PSI $\left(\Phi_{\text {re10 }}\right)$, performance index for the photochemical activity $\left(\mathrm{PI}_{\mathrm{abs}}\right)$, total performance index for the photochemical activity $\left(\mathrm{PI}_{\mathrm{tot}}\right)$, trapped energy flux per reaction center $\left(\mathrm{TR}_{0} / \mathrm{RC}\right)$, electron transport flux per reaction center $\left(\mathrm{ET}_{0} / \mathrm{RC}\right)$ (Table $4 \mathrm{~S}$, supplement available online). In both lettuce cultivars, all parameters of the quantum yield and specific energy fluxes excluding $\Phi_{\mathrm{do}}$, $\Phi_{\text {re10 }}$, and $\mathrm{PI}_{\text {tot }}$ decreased significantly with $\mathrm{FeD}, \mathrm{ZnD}$, and $\mathrm{MnD}$. The $\Phi_{\mathrm{do}}$ value increased in the plants grown under micronutrient deficiency condition. The highest $\Phi_{\text {do }}$ value was recorded in crisphead cultivar, which was grown under FeD (Table 2). Results were completely different for $\Phi_{\text {re10 }}$ and $\mathrm{PI}_{\text {tot }}$. Plants grown under $\mathrm{MnD}$ showed the highest increase in $\Phi_{\text {re10 }}$ and $\mathrm{PI}_{\text {tot }}$ and plants under $\mathrm{ZnD}$ showed the least increase in $\Phi_{\text {re10 }}$ and $\mathrm{PI}_{\text {tot }}$ compared with control. FeD had no significant effect on $\Phi_{\text {re10 }}$ compared with the control treatment but $\mathrm{PI}_{\text {tot }}$ decreased remarkably under FeD (Table 2).

Dry mass: Plant growth was determined by DM. DM showed statistically significant variations caused by effects of variety and micronutrient deficiency (Table 4S). As expected, the highest DM was recorded under control conditions and leaf lettuce was significantly superior to crisphead. Regardless of lettuce cultivars, the reduction rate of $\mathrm{DM}$ under $\mathrm{FeD}, \mathrm{ZnD}$, and $\mathrm{MnD}$ conditions were 43, 22 , and $11 \%$, respectively (Fig. 3 ). 


\section{Discussion}

Ion concentrations: Different response to micronutrient shortage was observed in both lettuce cultivars. As Fe, Zn, and $\mathrm{Mn}$ are divalent elements, they show antagonistic behavior during absorption. Therefore, a high concentration of each element in a nutrient solution could affect absorption of other elements. Generally, especial transporters, i.e., zinc transporters proteins (ZIP), are involved in absorbing these elements. Therefore amount of ZIP transporters is essential for the metal homeostasis in the plant (Milner et al. 2013). Some studies reported antagonistic effects of microelements in soybean (IzaguirreMayoral and Sinclair 2005), wheat (Zhao et al. 2011), and cucumber (Bityutskii et al. 2014), which is in agreement with our results.

Increasing $\mathrm{Zn}$ and $\mathrm{Mn}$ absorption through roots by iron-regulated transporter 1 (IRT1) can increase $\mathrm{Zn}$ and Mn concentration in lettuce leaves. In FeD conditions, IRT1 plays an important role as a regulator protein (Pavlovic et al. 2013). On the other hand, at ZnD, ZIP transporters increase amount of Fe and Mn (Sinclair and Krämer 2012). Zhao et al. (2011) suggested three reasons for antagonistic effects of $\mathrm{Fe}$ and $\mathrm{Zn}$ including: (1) a competition for uptake by transporters located on root cells, (2) disorder in metal chelation process in roots, (3) a competition for entering to xylem cells.

Osmotic pressure-regulating compounds: Micronutrient shortage increased amount of osmoregulators significantly, e.g., proline, soluble sugars, and phenolic compounds. Both lettuce cultivars showed higher concentrations of osmoregulators under the FeD treatment, comparing to $\mathrm{ZnD}$ and $\mathrm{MnD}$ treatments. The osmoregulators had positive effects on preventing plants from environmental stresses and improving stress tolerance in plants (Cesco et al. 2010). Phenolic compounds are also considered as an osmolite, which increases under FeD conditions (Valentinuzzi et al. 2015). Increasing phenolic

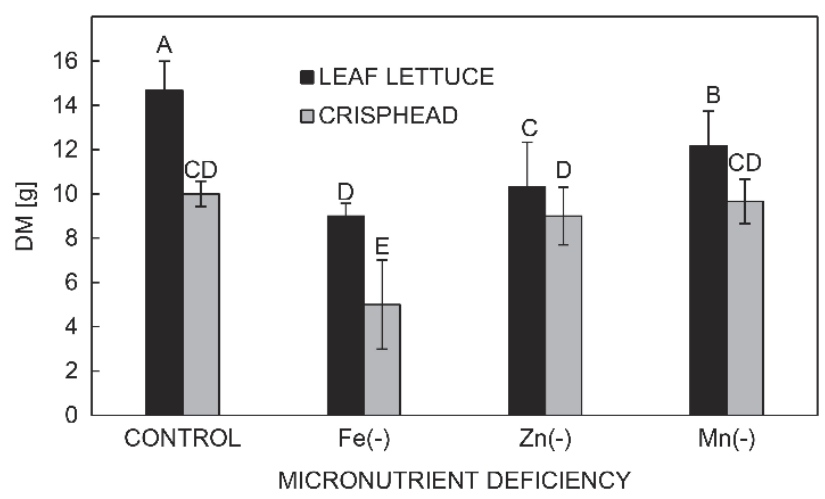

Fig. 3. Effect of micronutrient deficiency on dry mass (DM) of two lettuce cultivars: leaf lettuce and crisphead lettuce. Bars indicate standard error. Columns with different letters are significantly different at $P \geq 0.05$ compounds as a result of FeD conditions caused: (1) increasing $\mathrm{Fe}$ movement in apoplast, (2) improving $\mathrm{Fe}$ solubility in rhizosphere, (3) increasing available Fe by auxin and siderophores synthesis. Previous studies reported more proline under FeD condition in strawberry (Heidari and Sarani 2012, Valentinuzzi et al. 2015), chamomile (Heidari and Sarani 2012), and barley (AriasBaldrich et al. 2015). Proline production may increase as a result of higher amount of NADH compared to $\mathrm{NAD}^{+}$ which causes disorganization in the electron transport chain (Saradhi et al. 1993). On the other hand, proline reduces the disorganization of electron transport chain. Effects of $\mathrm{MnD}$ and $\mathrm{ZnD}$ on amount of osmoregulators was not well studied. Hajiboland and Amirazad (2010) reported a significant reduction of water-soluble carbohydrates in leaves and roots of cabbage under $\mathrm{ZnD}$. A significant increase of the proline content under $\mathrm{ZnD}$ was also reported in plants and it confirms our results (Jamalomidi et al. 2006). Mn and Fe shortage cause an increase in amounts of free radicals, which can be explained by the role of $\mathrm{Mn}$ and $\mathrm{Fe}$ in electron transport chain and enzymatic activities. Production of osmotic regulators, e.g., phenolic compounds, water soluble carbohydrates, and proline, is a defense strategy against free radicals (Hayat et al. 2012).

Photosynthetic pigments: Amount of Chl $a, b$, and TChl decreased significantly under micronutrient-shortage conditions. Leaf lettuce cultivar showed higher amounts of Chl $a$ and TChl, comparing to the crisphead cultivar. Reducing Chl content under microelement-shortage treatments could be explained by their effects on disruption of photosynthetic pigment production process, especially of Chl. Several factors are responsible for pigment decline under micronutrient-deficiency conditions. Data showed that FeD treatment was more effective in the reduction of photosynthetic pigments comparing to $\mathrm{ZnD}$ and $\mathrm{MnD}$ treatments. The important role of $\mathrm{Fe}$ for $\mathrm{Chl}$ and chloroplast functions can be the main reason. Fe plays a key role in oxidation and reduction mechanism in hem of cytochrome (Marschner 2011). Decreasing Chl pigments under FeD conditions was previously reported in pepper (Roosta and Mohsenian 2012), tomato (Machold and Stephan 1969), pea (Mahmoudi et al. 2005), and strawberry (Pestana et al. 2012). $\mathrm{Zn}$ is necessary for enzymatic activities and electron transport chain, so its shortage increases free radicals and damages of chloroplast membranes. $\mathrm{ZnD}$ also causes changes in Chl structure and a reduction in photosynthesis capacity. Reduction in the $\mathrm{Chl}$ content as a result of $\mathrm{ZnD}$ treatment was previously reported by $\mathrm{Fu}$ et al. (2015). Damages to thylakoid membranes and LHC proteins might be the main reason of $\mathrm{Chl}$ reduction. Effects of $\mathrm{MnD}$ on the $\mathrm{Chl}$ content is not well understood. Singh et al. (2001) reported significant decline in $\mathrm{Chl}$ in mint plants as a result of $\mathrm{MnD}$ treatment. 
Chl fluorescence: All Chl fluorescence parameters, except $\mathrm{V}_{\mathrm{i}}$, changed significantly under $\mathrm{FeD}, \mathrm{ZnD}$, and $\mathrm{MnD}$ conditions. The changes were smaller in leaf lettuce cultivar than those in crisphead cultivar. As PSII is located in thylakoid membranes, reducing thylakoid membrane stability under stress condition causes lower efficiency of PSII reaction centers. Changes in Chl fluorescence are useful parameters for measuring stability and efficiency of thylakoid membranes (Weng et al. 2008). Kalaji et al. (2014) have used Chl fluorescence to evaluate the performance of PSII and PSI under nutrient-deficiency condition $(\mathrm{K}, \mathrm{Mg}, \mathrm{Ca}, \mathrm{N}$, and $\mathrm{S}$ ) in tomato and maize. $\mathrm{Fu}$ et al. (2015) also utilized this method for apple trees under $\mathrm{ZnD}$ conditions. These reports confirm that $\mathrm{Fe}, \mathrm{Zn}$, and $\mathrm{Mn}$ shortage could affect different parts of photosynthetic apparatus. Increasing $\mathrm{V}_{\mathrm{j}}$ in such a situation is a result of reduction in quinone a and plastoquinone (PQ), which reduces electron transport (Kalaji et al. 2014). $\mathrm{F}_{\mathrm{v}} / \mathrm{F}_{\mathrm{m}}$ decline under $\mathrm{FeD}, \mathrm{ZnD}$, and $\mathrm{MnD}$ may occur as a result of damages to PSII reaction centers. Increasing amounts of free electrons and radicals under micronutrient-deficiency conditions are one of the main reason of such a damage (Roháček and Barták 1999, Breštič et al. 2015). $\mathrm{F}_{\mathrm{v}} / \mathrm{F}_{\mathrm{m}}$ reduction under $\mathrm{ZnD}$ treatment was previously reported by Khan and Khan (2014) in coward and under FeD by Osório et al. (2014) in strawberry. Generally, after decreasing $\mathrm{Q}_{\mathrm{A}}$ or after PQ oxidation, Chl fluorescence increases, which causes reaction center inactivation, and increases $F_{o}$ and decrease $F_{m}$ (Duysens and Sweers 1963). Based on the O-J-I-P curve, reduction in PQ capacity and other receptors, in both reaction centers, is the main reason of decreasing Chl fluorescence parameters (Strasser et al. 2010). Therefore a rapid increase in fluorescence parameters from $\mathrm{J}$ to I requires high PQ capacity, otherwise, process can result in a decrease of $F_{m}$ and then the Area and other $\mathrm{Chl}$ fluorescence parameters start declining.

Quantum yields and specific energy fluxes: $\mathrm{FeD}, \mathrm{ZnD}$, and $\mathrm{MnD}$ reduced quantum yield parameters, excluding $\Phi_{\mathrm{do}}, \Phi_{\mathrm{re} 10}$, and $\mathrm{PI}_{\text {tot. }}$. Reduction in quantum yield of PSII and electron transport has been reported in sunflower

\section{References}

Aravind P., Prasad M.N.V.: Zinc protects chloroplasts and associated photochemical functions in cadmium exposed Ceratophyllum demersum L., a freshwater macrophyte. - Plant Sci. 166: 1321-1327, 2004.

Arias-Baldrich C., Bosch N., Begines D. et al.: Proline synthesis in barley under iron deficiency and salinity. - J. Plant Physiol. 183: 121-129, 2015.

Barker A.V., Pilbeam D.J.: Handbook of Plant Nutrition. Pp. 392-457. CRC Press, New York 2015.

Beauchemin R., Gauthier A., Harnois J. et al.: Spermine and spermidine inhibition of photosystem II: disassembly of the oxygen evolving complex and consequent perturbation in electron donation from Tyr Z to $\mathrm{P}_{680^{+}}$and the quinone ac-

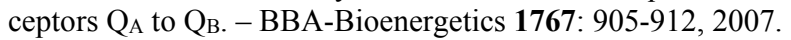

(Ciompi et al. 1996), maize, and tomato (Kalaji et al. 2014). They suggested that this decline occurrs due to decrease of LHC proteins in PSII. Decreasing photosynthetic pigments combined with lower transported energy and damages to D1 protein can cause $\varphi_{\text {Po }}$ reduction under stress conditions (Qu et al. 2012). Less transported electrons from PHQ to PC could be another reason for the reduction in the quantum yield of PSII (Strasser et al. 2010). Beauchemin et al. (2007) suggested that micronutrient, especially $\mathrm{FeD}$, deficiency reduces $\mathrm{Q}_{\mathrm{A}}$ reoxidation and inhibits transported electrons from $\mathrm{Q}_{\mathrm{A}}$ to $\mathrm{Q}_{\mathrm{B}}$. According to the important role of $\mathrm{Fe}, \mathrm{Zn}$, and $\mathrm{Mn}$ in electron transport chain, reduction in these microelements also decreases efficiency of electron acceptors in the electron transport chain which causes decline in transported electrons between PSI and PSII (Strasser et al. $2010)$. Wasted energy in a form of heat causes $\Phi_{\text {do }}$ raise under microelement-scarcity conditions (Kalaji et al. 2014). Decreasing $\mathrm{PI}_{\mathrm{abs}}$ and $\mathrm{PI}_{\text {tot }}$ could be also explained by a lowered number of transferred electrons.

Conclusion: We showed that $\mathrm{Fe}, \mathrm{Zn}$ and $\mathrm{Mn}$ shortage significantly reduced photosynthetic pigments ( $\mathrm{Chl} a, \mathrm{Chl}$ $b$, and TChl), Chl fluorescence parameters $\left(\mathrm{F}_{\mathrm{v}} / \mathrm{F}_{\mathrm{m}}\right.$, Area, $\mathrm{V}_{\mathrm{i}}, \mathrm{V}_{\mathrm{j}}, \mathrm{F}_{\mathrm{v}} / \mathrm{F}_{\mathrm{o}}, \mathrm{S}_{\mathrm{m}}$, and PI) and quantum yield of PSII ( $\Psi_{\mathrm{o}}$, $\mathrm{ET}_{20}, \mathrm{PI}_{\mathrm{abs}}, \mathrm{TR}_{0} / \mathrm{RC}$, and $\mathrm{ET}_{0} / \mathrm{RC}$ ) in both lettuce cultivars. Reduction in chlorophyll fluorescence parameters, photosynthetic pigments, and quantum yield under Fe, $\mathrm{Zn}$ and Mn deficiency conditions confirmed their importance for photosynthesis and the electron transport chain. In addition, micronutrients can act as a cofactor for some enzymatic activities, especially for enzymes involved in pathways producing photosynthetic pigments.

Results also showed that osmoregulators, e.g., proline, soluble sugars, and phenolic compounds, were enhanced under Fe, Zn, and Mn deficiency treatment. Higher amount of osmoregulators in leaf lettuce confirmed the higher membrane stability and PSII efficiency in this cultivar. Eventually, we can recommend chlorophyll fluorescence parameters as a useful and accessible markers to determine tolerant cultivars for environmental stresses.

Bertamini M., Nedunchezhian N., Borghi B.: Effect of iron deficiency induced changes on photosynthetic pigments, ribulose-1,5-bisphosphate carboxylase, and photosystem activities in field grown grapevine (Vitis vinifera L. cv. Pinot noir) leaves. - Photosynthetica 39: 59-65, 2001.

Bityutskii N., Pavlovic J., Yakkonen K. et al.: Contrasting effect of silicon on iron, zinc and manganese status and accumulation of metal-mobilizing compounds in micronutrient-deficient cucumber. - Plant Physiol. Bioch. 74: 205-211, 2014.

Breštič M., Živčák M., Kunderlíková K. et al.: Low PSI content limits the photoprotection of PSI and PSII in early growth stages of chlorophyll $b$-deficient wheat mutant lines. Photosynth. Res. 125: 151-166, 2015.

Cesco S., Neumann G., Tomasi N. et al.: Release of plant-borne 
flavonoids into the rhizosphere and their role in plant nutrition. - Plant Soil 329: 1-25, 2010.

Chaves M.M., Maroco J.P., Pereira J.S.: Understanding plant responses to drought - from genes to the whole plant. - Funct. Plant Biol. 30: 239-264, 2003.

Ciompi S., Gentili E., Guidi L. et al.: The effect of nitrogen deficiency on leaf gas exchange and chlorophyll fluorescence parameters in sunflower. - Plant Sci. 118: 177-184, 1996.

Donnini S., Guidi L., Degl'Innocenti E. et al.: Image changes in chlorophyll fluorescence of cucumber leaves in response to iron deficiency and resupply. - J. Plant Nutr. Soil Sci. 176: 734742,2013

Duysens L., Sweers H.: Mechanism of two photochemical reactions in algae as studied by means of fluorescence. - In: Japanese Society of Plant Physiologists (ed.): Studies on Microalgae and Photosynthetic Bacteria. Pp. 353-372. Univ. of Tokyo Press, Tokyo 1963.

Evans J.R., Terashima I.: Effects of nitrogen nutrition on electron transport components and photosynthesis in spinach. - Funct. Plant Biol. 14: 59-68, 1987.

Fu C., Li M., Zhang Y. et al.: Morphology, photosynthesis, and internal structure alterations in field apple leaves under hidden and acute zinc deficiency. - Sci. Hortic.-Amsterdam 193: 4754, 2015.

Hajiboland R., Amirazad F.: Growth, photosynthesis and antioxidant defense system in $\mathrm{Zn}$-deficient red cabbage plants. - Plant Soil Environ. 56: 209-217, 2010

Hayat S., Hayat Q., Alyemeni M.N. et al.: Role of proline under changing environments: a review. - Plant Signal. Behav. 7: 1456-1466, 2012.

Heidari M., Sarani S.: Growth, biochemical components and ion content of chamomile (Matricaria chamomilla L.) under salinity stress and iron deficiency. - J. Saudi Society Agri. Sci. 11: 37-42, 2012.

Henriques F.S.: Loss of blade photosynthetic area and of chloroplasts photochemical capacity account for reduced $\mathrm{CO}_{2}$ assimilation rates in zinc-deficient sugar beet leaves. - J. Plant Physiol. 158: 915-919, 2001.

Isfendiyaroglu M., Ozeker E.: The relation between phenolic compound and seed dormancy in pistachios and almond. Cahiers Opt. Mediterr. 56: 232-277, 2002

Izaguirre-Mayoral M., Sinclair T.: Soybean genotypic difference in growth, nutrient accumulation and ultrastructure in response to manganese and iron supply in solution culture. - Ann. Bot.London 96: 149-158, 2005.

Jamalomidi M., Esfahani M., Carapetian J.: Zinc and salinity interaction on agronomical traits, chlorophyll and proline content in lowland rice (Oryza sativa L.) genotypes. - Pak. J. Biol. Sci. 9: 1315-1319, 2006.

Kalaji H.M. Loboda T.: Photosystem II of barley seedlings under cadmium and lead stress. - Plant Soil Environ. 53: 511-516, 2007.

Kalaji H.M., Oukarroum A., Alexandrov V. et al.: Identification of nutrient deficiency in maize and tomato plants by in vivo chlorophyll $a$ fluorescence measurements. - Plant Physiol. Bioch. 81: 16-25, 2014.

Kautsky H., Hirsch A.: [New experiments on carbonic acid assimilation.] - Naturwissenschaften 19: 964-964, 1931. [In German]

Khan M.I.R., Khan N.A.: Ethylene reverses photosynthetic inhibition by nickel and zinc in mustard through changes in PSII activity, photosynthetic nitrogen use efficiency, and antioxidant metabolism. - Protoplasma 251: 1007-1019, 2014.
Lichtenthaler R.: Chlorophylls and carotenoids - pigments of photosynthetic biomembranes. - Methods Enzymol.148: 350382, 1987.

Machold O., Stephan U.: The function of iron in porphyrin and chlorophyll biosynthesis. - Phytochemistry 8: 2189-2192, 1969.

Mahmoudi H., Ksouri R., Gharsalli M. et al.: Differences in responses to iron deficiency between two legumes: lentil (Lens culinaris) and chickpea (Cicer arietinum). - J. Plant Physiol. 162: 1237-1245, 2005.

Marschner H.: Marschner's Mineral Nutrition of Higher Plants. Pp. 191-243. Academic Press, London 2011.

Milner M.J., Seamon J., Craft E. et al.: Transport properties of members of the ZIP family in plants and their role in $\mathrm{Zn}$ and Mn homeostasis. - J. Exp. Bot. 64: 369-381, 2013.

Morales F., Abadía A., Abadía J.: Chlorophyll fluorescence and photon yield of oxygen evolution in iron-deficient sugar beet (Beta vulgaris L.) leaves. - Plant Physiol. 97: 886-893, 1991.

Osório J., Osório M.L., Correia P.J. et al.: Chlorophyll fluorescence imaging as a tool to understand the impact of iron deficiency and resupply on photosynthetic performance of strawberry plants. - Sci. Hortic.-Amsterdam 165: 148-155, 2014.

Oukarroum A., Bussotti F., Goltsev V. et al.: Correlation between reactive oxygen species production and photochemistry of photosystems I and II in Lemna gibba L. plants under salt stress. - Environ. Exp. Bot. 109: 80-88, 2015

Pavlovic J., Samardzic J., Maksimović V. et al.: Silicon alleviates iron deficiency in cucumber by promoting mobilization of iron in the root apoplast. - New Phytol. 198: 1096-1107, 2013.

Percival G., Henderson A.: An assessment of the freezing tolerance of urban trees using chlorophyll fluorescence. - J. Hortic. Sci. Biotech. 78: 254-260, 2003.

Pestana M., Correia P.J., Saavedra T. et al.: Development and recovery of iron deficiency by iron resupply to roots or leaves of strawberry plants. - Plant Physiol. Bioch. 53: 1-5, 2012.

Petrazzini L.L., Souza G.A., Rodas C.L. et al.: Nutritional deficiency in crisphead lettuce grown in hydroponics. - Hortic. Bras. 32: 310-313, 2014.

Qu C., Gong X., Liu C. et al.: Effects of manganese deficiency and added cerium on photochemical efficiency of maize chloroplasts.- Biol. Trace. Elem. Res. 146: 94-100, 2012.

Roháček K., Barták M.: Technique of the modulated chlorophyll fluorescence: basic concepts, useful parameters, and some applications. - Photosynthetica 37: 339-363, 1999.

Roosta H.R., Schjoerring J.K.: Effects of ammonium toxicity on nitrogen metabolism and elemental profile of cucumber plants. - J. Plant Nutr. 30: 1933-1951, 2007.

Roosta H.R., Mohsenian Y.: Effects of foliar spray of different Fe sources on pepper (Capsicum annum L.) plants in aquaponic system. - Sci. Hortic.-Amsterdam 146: 182-191, 2012.

Saradhi P.P., Alia, Vani B.: Inhibition of mitochondrial electron transport is the prime cause behind proline accumulation during mineral deficiency in Oryza sativa. - Plant Soil 155: 465-468, 1993.

Shangguan Z., Shao M., Dyckmans J.: Effects of nitrogen nutrition and water deficit on net photosynthetic rate and chlorophyll fluorescence in winter wheat. - J. Plant Physiol. 156: 46-51, 2000.

Sinclair S.A., Krämer U.: The zinc homeostasis network of land plants. - BBA-Mol. Cell. Biol. L. 1823: 1553-1567, 2012.

Singh P., Misra A., Srivastava N.K.: Influence of Mn deficiency on growth, chlorophyll content, physiology, and essential 
monoterpene oil(s) in genotypes of spearmint (Mentha spicata L.). - Photosynthetica 39: 473-476, 2001.

Sperotto R.A., Ricachenevsky F.K., Fett, J.P.: Iron deficiency in rice shoots: identification of novel induced genes using RDA and possible relation to leaf senescence. - Plant Cell Rep. 26: 1399-1411, 2007.

Strasser R.J., Srivastava A., Tsimilli-Michael M.: The fluorescence transient as a tool to characterize and screen photosynthetic samples. - In: Yunus M., Pathre U., Mohanty P. (ed.): Probing Photosynthesis: Mechanisms, Regulation and Adaptation. Pp. 445-483, Taylor and Francis, London 2000.

Strasser R.J., Tsimilli-Michael M., Qiang S. et al.: Simultaneous in vivo recording of prompt and delayed fluorescence and 820 $\mathrm{nm}$ reflection changes during drying and after rehydration of the resurrection plant Haberlea rhodopensis. - BBABioenergetics 1797: 1313-1326, 2010.

Suzuki M., Bashir K., Inoue H. et al.: Accumulation of starch in Zn-deficient rice. - Rice 5: 9, 2012.

Terry N., Abadía J.: Function of iron in chloroplasts. - J. Plant Nutr. 9: 609-646, 1986.

Timperio A.M., D'Amici G.M., Barta C. et al.: Proteomics, pigment composition, and organization of thylakoid membranes in iron-deficient spinach leaves. - J. Exp. Bot. 58: 36953710, 2007.

Tuba Z., Saxena D.K., Srivastava K. et al.: Chlorophyll $a$ fluorescence measurements for validating the tolerant bryophytes for heavy metal $(\mathrm{Pb})$ biomapping. - Curr. Sci. 98: 1505-1508, 2010.

Valentinuzzi F., Pii Y., Vigani G. et al.: Phosphorus and iron deficiencies induce a metabolic reprogramming and affect the exudation traits of the woody plant Fragaria $\times$ ananassa. $-\mathbf{J}$. Exp. Bot. 66: 6483-6495, 2015.

Weng J.K., Li X., Bonawitz N.D. et al.: Emerging strategies of lignin engineering and degradation for cellulosic biofuel production. - Curr. Opin. Biotech. 19: 166-172, 2008.

Xue H., Aziz R.M., Sun N. et al:: Inhibition of cellular transformation by berry extracts. - Carcinogenesis 22: 351356, 2001.

Zhao A.Q., Bao Q.L., Tian X.H. et al.: Combined effect of iron and zinc on micronutrient levels in wheat (Triticum aestivum L.). - J. Env. Biol. 32: 235-239, 2011.

\section{Appendix}

(Breštič and Živčák 2013)

\begin{tabular}{|c|c|c|}
\hline \multirow{2}{*}{\multicolumn{3}{|c|}{$\begin{array}{l}\mathrm{Ab} \\
\text { Basic parameters derived from the extracted data }\end{array}$}} \\
\hline & & \\
\hline$\overline{F_{0}}$ & Minimal fluorescence, when all PSII RCs are open & $\mathrm{F}_{\mathrm{o}}=\mathrm{F}_{50 \mu \mathrm{s}}$ \\
\hline $\mathrm{F}_{\mathrm{m}}$ & Maximal fluorescence, when all PSII RCs are closed & \\
\hline $\mathrm{F}_{\mathrm{v}}$ & Maximal variable fluorescence & $\mathrm{F}_{\mathrm{v}}=\mathrm{F}_{\mathrm{m}}-\mathrm{F}_{\mathrm{o}}$ \\
\hline $\mathrm{F}_{\mathrm{v}} / \mathrm{F}_{\mathrm{m}}$ & Maximal quantum yield of PSII photochemistry & \\
\hline $\mathrm{V}_{\mathrm{j}}$ & Relative variable fluorescence at the J-step & $V_{j}=\left(F_{2 m s}-F_{o}\right) /\left(F_{m}-F_{o}\right)$ \\
\hline $\mathrm{V}_{\mathrm{i}}$ & Relative variable fluorescence at time $30 \mathrm{~ms}$ (I-step) after start of actinic light pulse & $\mathrm{V}_{\mathrm{i}}=\left(\mathrm{F}_{30 \mathrm{~ms}}-\mathrm{F}_{\mathrm{o}}\right) /\left(\mathrm{F}_{\mathrm{m}}-\mathrm{F}_{\mathrm{o}}\right)$ \\
\hline Area & Area above the OJIP curve; it express the size of the reduced PQ pool & \\
\hline $\mathrm{Sm}$ & $\begin{array}{l}\text { Normalized area; it is related to the number of electron carriers per } \\
\text { electron transport chain }\end{array}$ & $\mathrm{Sm}=\left(\right.$ Area $/\left(\mathrm{F}_{\mathrm{m}}-\mathrm{F}_{\mathrm{o}}\right)$ \\
\hline \multicolumn{3}{|c|}{ Quantum yields } \\
\hline$\overline{\Psi_{\mathrm{o}}}$ & $\begin{array}{l}\text { Probability that a trapped exiton moves an electron in to the electron transport } \\
\text { chain beyond } \mathrm{Q}_{\mathrm{A}}\end{array}$ & $\Psi_{\mathrm{o}}=\left(1-\mathrm{V}_{\mathrm{j}}\right)$ \\
\hline$\varphi$ Po & Maximum quantum yield of primary PSII photochemistry & $\varphi P_{0}=1-\left(F_{0} / F_{m}\right)$ \\
\hline$\Phi_{\mathrm{do}}$ & Quantum yield of energy dissipation & $\Phi_{\mathrm{do}}=\mathrm{F}_{\mathrm{o}} / \mathrm{F}_{\mathrm{m}}$ \\
\hline$\varphi \mathrm{ET}_{20}$ & Quantum yield of electron transport from $\mathrm{Q}_{\mathrm{A}}$ to $\mathrm{Q}_{\mathrm{B}}$ in PSII & $\varphi \mathrm{ET} 20=\varphi \mathrm{P}_{\mathrm{o}}\left(1-\mathrm{V}_{\mathrm{j}}\right)$ \\
\hline$\varphi \mathrm{RE}_{10}$ & Quantum yield of reduction of end electron acceptors at the PSI acceptor side & $\varphi \mathrm{RE}_{10}=\varphi \mathrm{P}_{\mathrm{o}}\left(1-\mathrm{V}_{\mathrm{i}}\right)$ \\
\hline $\mathrm{PI}_{\mathrm{ABS}}$ & $\begin{array}{l}\text { Performance index for the photochemical activity (basic formula on } \\
\text { absorption basis) }\end{array}$ & $\begin{array}{l}\mathrm{PI}_{\mathrm{ABS}}=\left[\left(1-\left(\mathrm{F}_{\mathrm{o}} / \mathrm{F}_{\mathrm{m}}\right)\right] /\right. \\
\left(\mathrm{M}_{\mathrm{o}} / \mathrm{V}_{\mathrm{j}}\right) \cdot\left[\left(\mathrm{F}_{\mathrm{m}}-\mathrm{F}_{\mathrm{o}}\right) / \mathrm{F}_{\mathrm{o}}\right]\left[\left(1-\mathrm{V}_{\mathrm{j}}\right) \mathrm{V}_{\mathrm{i}}\right]\end{array}$ \\
\hline PItot & $\begin{array}{l}\text { Total performance index for the photochemical activity (including the flow } \\
\text { beyond PSI) }\end{array}$ & $\mathrm{PI}_{\text {tot }}=\mathrm{PI}_{\mathrm{ABS}}\left(1-\mathrm{V}_{\mathrm{i}}\right) /\left(1-\mathrm{V}_{\mathrm{j}}\right)$ \\
\hline \multicolumn{3}{|c|}{ Specific energy fluxes ( per QA-reducing PSII reaction center) } \\
\hline $\mathrm{TR}_{0} / \mathrm{RC}$ & trapped energy flux per RC (at $t=0)$ & Mo $\left(1 / V_{j}\right)$ \\
\hline $\mathrm{ET} / \mathrm{RC}$ & electron transport flux per $\mathrm{RC}($ at $\mathrm{t}=0)$ & $\operatorname{Mo~}\left(1 / V_{j}\right) \psi_{o}$ \\
\hline
\end{tabular}

